\title{
PENENTUAN WAKTU OPTIMUM PREVENTIVE MAINTENANCE PADA MESIN PELLET MILL DI PT JAPFA COMFEED INDONESIA, Tbk. UNIT MARGOMULYO MENGGUNAKAN METODE GEOMETRIC PROCESS
}

\author{
Zahrina Luthfi Raudina ${ }^{[1]}$, Agus Suharsono ${ }^{[2]}$ dan Haryono ${ }^{[3]}$ \\ ${ }^{[1][2][3]}$ Departemen Statistika, Fakultas Matematika, Komputasi, dan Sains Data, \\ Institut Teknologi Sepuluh Nopember (ITS) \\ J1. Arief Rahman Hakim, Surabaya 60111 Indonesia \\ Email: zahrina39@gmail.com ${ }^{[1]}$,agus_s@statistika.its.ac.id ${ }^{[2]}$,dan haryono@ statistika.its.ac.id ${ }^{[3]}$
}

\begin{abstract}
Abstrak-PT Japfa Comfeed Indonesia, Tbk. Unit Margomulyo merupakan perusahaan yang berfokus pada kebutuhan pakan ternak khususnya ternak ayam broiler. Proses produksi pakan ternak dibantu oleh beberapa mesin salah satunya adalah mesin Pellet Mill. Mesin Pellet Mill merupakan mesin yang berfungsi untuk pembentukan pellet pada pakan ternak. Beberapakali mesin Pellet Mill mengalami kerusakan ditengah proses produksi, sehingga mengganggu proses produksi. Perbaikan pada mesin tidak selamanya efisien karena semakin sering mesin mengalami perbaikan maka keandalan mesin akan semakin menurun dan laju kerusakan semakin meningkat seiring bertambahnya waktu. Geometric Process merupakan metode yang sesuai untuk memodelkan permasalahan tersebut karena mesin setelah mengalami perbaikan maka dianggap memiliki kinerja dan keandalan yang menurun secara linier. Pada penelitian ini bertujuan untuk menentukan waktu optimum perusahaan melakukan tindakan pemeliharaan pada mesin Pellet Mill 5.12 dan 8.12 berupa perbaikan, pengecekan seluruh komponen, dan melakukan penggantian komponen. Hasil penelitian menunjukkan waktu optimum untuk pemeliharaan mesin Pellet Mill 5.12 adalah pada kerusakan ke-8 dengan estimasi ratarata biaya jangka panjang sebesar $R p 3.812 .096$ perjam dan pada mesin Pellet Mill 8.12 pada kerusakan ke-7 dengan estimasi rata-rata biaya jangka panjang $R p$ 7.344.398 perjam
\end{abstract}

Kata Kunci: Geometric Process, Mesin Pellet Mill, Preventive Maintenance.

\section{PENDAHULUAN}

$\mathrm{P}$ T Japfa Comfeed Indonesia, Tbk Unit Margomulyo merupakan perusahaan penghasil pakan ternak ayam broiler. Meningkatnya permintaan pakan ternak di Indonesia menyebabkan PT Japfa Comfeed Indonesia, Tbk Unit Margomulyo harus mampu bersaing dalam meningkatkan kapasitas produksi agar memenuhi kebutuhan konsumen dan menjaga kualitas. Kualitas produk bergantung dengan adanya mesin produksi [1]. Mesin dikatakan baik bila output maksimal dan minim kerusakan. Namun selama ini, proses produksi di Unit Margomulyo sering mengalami downtime akibat dari mesin yang mengalami kerusakan ditengah produksi. Hal tersebut menjadi permasalahan perusahaan dalam mememuhi target produksi. Di lain sisi, perusahaan telah melakukan perawatan dan perbaikan mesin dengan biaya yang tidak sedikit.

Perbaikan pada mesin yang rusak tidak selamanya efisien. Jika mesin yang rusak mengalami beberapa kali perbaikan, maka keandalan dari mesin ini akan semakin menurun dan laju kerusakannya semakin meningkat seiring dengan bertambahnya waktu [2]. Di Unit Margomulyo, mesin yang sering mengalami kerusakan adalah mesin Pellet Mill. Padahal Mesin Pellet Mill merupakan mesin yang sangat penting sebagai mesin produksi akhir yang dihasilkan oleh Unit Margomulyo yaitu berupa pellet dan crumble (pecahan pellet). Sehingga Mesin Pallet Mill harus dalam keadaan baik agar dapat menunjang produksi pada perusahaan pakan ternak ini. Oleh karena itu perusahaan perlu menerapkan salah satu metode statistika dalam bentuk evaluasi untuk menentukan waktu perbaikan atau penggantian komponen. Menurut Lam, permasalahan dalam mesin yang mengalami penurunan kinerja setelah dilakukan perbaikan dapat dimodelkan dengan Geometric Process [3].

Geometric Process menyatakan bahwa sistem yang diperbaiki maka akan dianggap memiliki kinerja dan keandalan yang menurun. Pada tahun 2000, Leung dan Fong melakukan penelitian untuk melakukan penggantian gearbox bus dengan metode Geometric Process [4]. Selain itu, Puspitasari pada tahun 2016 melakukan penelitian untuk mengetahui waktu optimum perawatan berupa penggantian komoponen ACM pada pesawat terbang CRJ-1000 dan didapatkan waktu yang optimum pada kerusakan ke-4 [5]. Pada penelitian ini data yang digunakan adalah data sekunder dari data Lifetime mesin Pellet Mill di PT Japfa Comfeed Indonesia, Tbk Unit Margomulyo pada tahun 2012 sampai 2017 dari bagian teknik. Dengan menggunakan metode Geometric Process diharapkan dapat menentukan waktu optimum preventive maintenance berupa perbaikan dan penggantian komponen dengan biaya minimum dari mesin Pellet Mill PT Japfa Comfeed Indonesia, Tbk Unit Margomulyo.

\section{TINJAUAN PUSTAKA}

A. Geometric Process

Dalam masalah pemeliharaan, banyak mesin yang sering mengalami penurunan kinerja setelah dilakukan perbaikan. Berdasarkan fenomena ini, Lam pada tahun 1998 pertama kali mengusulkan sebuah pendekatan Geometric Process (GP) untuk memodelkan fenomena tersebut [6]. Geometric Process (GP) dianggap lebih realistis, relevan, dan langsung memodelkan karakteristik sistem suatu mesin dan dapat memodelkan operasi mesin secara berturut-turut [3]. Menurut Lam, terdapat dua definisi Geometric Process (GP) yang diberikan sebagai berikut.

Definisi 1. Diberikan variabel random $G_{l}, G_{2}, \ldots$ untuk $r>0,\left\{\mathrm{r}^{\mathrm{n}-1} G_{n}, n=1,2, \ldots\right\}$ membentuk suatu Renewal Process (RP) maka $\left\{G_{n}, n=1,2, \ldots\right\}$ merupakan suatu 
Geometric Process (GP), $r$ disebut sebagai rasio atau parameter dari Geometric Proceess (GP).

Definisi 2. Jika $r>1$, maka Geometric Process (GP) tersebut merupakan suatu Geometric Process (GP) yang menurun. Jika $0<r<1$, maka Geometric Process (GP) tersebut merupakan suatu Geometric Process (GP) yang meningkat. Jika $r=1$, maka Geometric Process (GP) merupakan suatu Renewal Process (RP) dengan

\section{$G_{n} \quad=$ Geometric Process}

Komponen yang mengalami penurunan keandalan dapat diasumsikan bahwa umur komponen membentuk Geometric Process (GP) yang menurun, sedangkan waktu perbaikan akan membentuk Geometric Process (GP) yang meningkat. Waktu penggantian komponen pada umumnya bersifat skotastik, sehingga tidak mempertimbangkan usia komponen.

B. Pemeriksaan Laplace

Suatu sistem yang bersifat Non-Homogeneus Poisson Process (NHPP) memiliki trend kerusakan yang naik ataupun turun. Menurut Adam, salah satu pemeriksaan trend yang dapat digunakan adalah nilai Laplace [7]. Perhitungan nilai Laplace mesin ke-k untuk time truncated data diberikan sebagai berikut.

$$
L=\frac{\frac{\sum_{n=1}^{N} T_{n}}{N}-\frac{T}{2}}{T_{n} \sqrt{\frac{1}{12(N)}}} \quad T_{n}=\sum_{i=1}^{n} G_{n}
$$

Dimana L merupakan pendekatan distribusi normal standar untuk $\mathrm{N}>3$ dan $T$ adalah time truncated yang telah ditentukan pada sistem. Jika nilai $L>0$ maka data set kerusakan $\left\{G_{l}, G_{2}, G_{3}, \ldots, G_{N}\right\}$ menunjukkan adanya trend naik, sedangkan jika nilai $L<0$ maka data set kerusakan $\left\{G_{l}, G_{2}, G_{3}, \ldots, G_{N}\right\}$ menunjukkan adanya trend turun [7].

C. Estimasi Parameter $\ln r, \alpha, \sigma_{e}^{2}$

Terdapat beberapa metode yang dapat digunakan untuk estimasi parameter, salah satunya adalah Ordinary Least Square. Lam menyatakan untuk mengestimasi paramater model geometric procees dengan persamaan regresi linier sederhana sebagai berikut [6].

$$
\ln G_{n}=-\ln r(n-1)+\alpha+e_{n}
$$

untuk $\mathrm{n}=1,2, \ldots, \mathrm{N}$

Dimana $e_{n}$ adalah bentuk error yang menjelaskan pengaruh (effect) variabel dependen $\ln G n$ dan $e_{n}$ adalah variabel random dengan mean 0 dan varians $\sigma_{e}^{2}$ untuk semua $\mathrm{n}=1,2, \ldots, \mathrm{N}$.

Menurut Lam pada tahun 1992, estimasi parameter ln $r$, $\alpha$, dan $\sigma_{e}^{2}$ dapat dilakukan dengan OLS dari persamaan regresi linier sederhana [3]. Estimasi titik menggunakan metode least square $\ln \mathrm{r}, \alpha$, dan $\sigma_{e}^{2}$ dihitung menggunakan formula

$$
\begin{gathered}
\ln \hat{r}=\frac{6}{(N-1) N(N+1)}\left[(N-1) \sum_{n=1}^{N} G_{n}-2 \sum_{n=1}^{N}(n-1) \ln G_{n}\right] \\
\widehat{\alpha}=\frac{\sum_{n=1}^{N} \ln G_{n}}{N}+\left(\frac{N-1}{2}\right) \ln \widehat{r} \\
\sigma_{e}^{2}=\frac{1}{N-2}\left\{\sum_{n=1}^{N}\left(\ln G_{n}\right)^{2}-\frac{\left(\sum_{n=1}^{N} \ln G_{n}\right)^{2}}{N}-\ln \hat{r}\left[\left(\frac{N-1}{2}\right) \sum_{n=1}^{N} \ln G_{n}-\sum_{n=1}^{N}(n-1) \ln G_{n}\right]\right\}
\end{gathered}
$$

\section{Uji Geometric Process}

Untuk menguji apakah data berasal dari Geometric Process (GP), dengan hipotesis sebagai berikut.

$H_{0}: r=1$ (rasio keandalan sama dengan 1 atau merupakan renewal process)

$H_{1}: r \neq 1$ (rasio keandalan tidak sama dengan 1 atau merupakan geometric process).

Statistik Uji:

$$
t=\frac{-\ln \hat{r} \sqrt{(N-1) N(N+1)}}{\hat{\sigma}_{e} \sqrt{12}}
$$

t berdistribusi student-t dengan derajat bebas $(N-2)$.

Jika $|\mathrm{t}|>$ nilai kritis $t_{(N-2) ; 0.025}$, maka $H_{0}$ ditolak pada level signifikansi $5 \%$ yang berarti data set $\left\{G_{1}, G_{2}, \ldots, G_{N}\right\}$ berasal dari Geometric Process [3].

\section{E. Estimasi Mean dan varians dari $\mathrm{G}_{\mathrm{n}}$}

Pertama, estimasi mean dan variansi dari $\mathrm{G}_{1}$ dilakukan dengan menggunakan estimator yang relevan. Persamaan yang digunakan adalah sebagai berikut.

a. Jika rasio $r>1$, estimasi mean dan variansi dari $\mathrm{G}_{1}$ sebagai berikut.

$$
\hat{\mu}_{G_{1}}=\frac{\left(1-\hat{r}^{-1}\right) \sum_{n=1}^{N} G_{n}}{1-\hat{r}^{-N}} \quad \text { ( } 7 \text { ) dan } \hat{\sigma}_{G_{1}}^{2}=\frac{\sum_{n=1}^{N}\left(\hat{r}^{n-1} G_{n}\right)^{2}-\frac{\left(\sum_{n=1}^{N} \hat{r}^{n-1} G_{n}\right)^{2}}{N}}{N-1}
$$

b. Jika $0<r<1, \mu_{G_{1}}$ diestimasi menggunakan persamaan berikut ini.

$$
2 \mu_{G_{1}}^{2} \ln \mu_{G_{1}}-2 \hat{\alpha} \mu_{G_{1}}^{2}-\sigma_{G_{1}}^{2}=0
$$

Dimana $\hat{\alpha}$ dan $\hat{\sigma}_{G_{1}}^{2}$ masing-masing ditentukan oleh persamaan (4) dan (7).

c. Jika $r=1$, estimasi $\mu_{G_{1}}$ dan $\hat{\sigma}_{G_{1}}^{2}$ masing-masing ditentukan sebagai berikut.

$$
\hat{\mu}_{G_{1}}=\frac{\sum_{n=1}^{N} G_{n}}{N} \text { dan } \hat{\sigma}_{G_{1}}^{2}=\frac{\sum_{n=1}^{N}\left(G_{n}-\hat{\mu} G_{1}\right)^{2}}{N-1}
$$

Kedua, estimasi mean dan varians dari $G_{n}$ untuk $n=2,3, \ldots N$ dengan menggunakan rumus sebagai berikut.

$$
\hat{\mu}_{G_{n}}=\frac{\hat{\mu} G_{1}}{\hat{r}^{n-1}} \text { dan } \hat{\sigma}_{G_{n}}^{2}=\frac{\hat{\sigma}^{2} G_{1}}{\hat{r}^{2(n-1)}}
$$

F. Kebijakan Waktu Optimal (Penggantian)

Diberikan $Z_{\mathrm{n}}$ merupakan waktu antara penggantian ke (n-1) dan penggantian ke-n dengan $Z_{0}=0$, maka $\left\{Z_{n}\right.$, $\mathrm{n}=1,2, \ldots\}$ membentuk renewal process. Menerapkan hasil yang telah diketahui dari teori renewal sebagai berikut [8]. $l(N)=\frac{\text { Total pendapatan yang diharapkan terjadi dalam siklus - Total biaya yang diharapkan }}{\text { panjang siklus yang diharapkan }}$ $l(N)=\frac{\text { Biaya yang diharapkan terjadi dalam siklus }}{\text { panjang siklus yang diharapkan }}$

Rata-rata biaya jangka panjang diberikan sebagai berikut.untuk $\mathrm{N}=1,2, \ldots$, dengan :

$$
l(N)=\frac{c_{f} \mu_{Y_{1}} \sum_{n=1}^{N-1} \frac{1}{b^{n-1}}+c_{R}-\mu_{X_{1}} \sum_{n=1}^{N} \frac{1}{a^{n-1}}}{\mu_{X_{1}} \sum_{n=1}^{N} \frac{1}{a^{n-1}}+\mu_{Y_{1}} \sum_{n=1}^{N-1} \frac{1}{b^{n-1}}}
$$

$C_{f} \quad$ = Biaya rata-rata perbaikan

$C_{R} \quad$ = Biaya rata-rata penggantian

$\alpha=$ Parameter Geometric Process umur mesin 
$b \quad=$ Parameter Geometric Process lama waktu perbaikan

$\mu_{X 1}=$ rata-rata umur mesin setelah kerusakan pertama

$\mu_{y 1}=$ rata-rata lama waktu perbaikan setelah kerusakan pertama

$l(N)$ = biaya rata-rata jangka panjang, fungsi dari jumlah kerusakan

Berikut ini adalah langkah-langkah dalam menentukan kebijakan waktu penggantian yang optimal.

1. Menghitung rata-rata biaya jangka panjang $l_{1}(N)$ untuk $N=1,2,3, \ldots$ menggunakan persamaan (2.13)

2. Plot rata-rata biaya jangka panjang $l_{l}(N)$ terhadap $\mathrm{N}$, kemudian dapat diperoleh waktu penggantian optimal yang ditunjukkan oleh titik minimum pada kurva

G. Proses Produksi di PT Japfa Comfeed Indonesia, Tbk Unit Margomulyo

Proses produksi di PT Japfa Comfeed Indonesia, Tbk Unit Margomulyo dibagi menjadi 4 section yaitu intake, dosing, press, dan finish product. Produksi hanya dilakukan di satu lokasi atau area. Berikut merupakan alur produksi pakan ternak di PT Japfa Comfeed Indonesia, Tbk Unit Margomulyo.

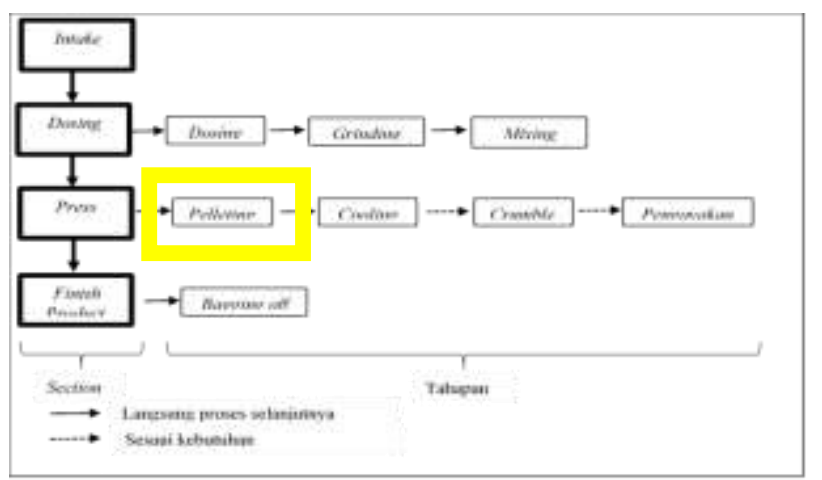

Gambar 1. Alur Proses Produksi

Proses pelleting dilakukan di dua line secara terpisah. Mesin-mesin yang mendukung dalam proses tersebut adalah feeder, conditioner, dan pellet mill. Di mesin pellet mill, tepung yang telah berubah tekstur dari Conditioner jatuh ke dalam press die. Didalam die terdapat dua roll berbentuk lingkaran yang berputar untuk menekan tepung ( $\mathrm{gel}$ ) sehingga melewati lubang-lubang silinder yang mengelilingi die. Diluar silinder terdapat pisau untuk memotong pelet yang keluar dari silinder secara stationer sesuai dengan ukuran yang diinginkan. Hasil pelet diteruskan ke mesin cooler. Terdapat dua mesin pellet mill yaitu mesin Pellet Mill 5.12 dan mesin Pellet Mill 8.12.

\section{METODOLOGI PENELITIAN}

\section{A. Sumber Data}

Data pada penelitian ini adalah data sekunder yang diperoleh dari PT. Japfa Comfeed Indonesia, Tbk Unit Margomulyo. Data merupakan data downtime mesin dan data lama waktu perbaikan mesin Pellet Mill 5.12 dan Pellet Mill 8.12 pada tahun 2012-2017. Data downtime dikonversikan menjadi data waktu antar kegagalan yang dianggap sebagai lamanya mesin bekerja atau umur mesin.

B. Variabel Penelitian
Variabel yang digunakan dalam penelitian ini adalah lamanya mesin bekerja (umur mesin) dalam satuan jam dan data perbaikan kerusakan mesin (lama waktu perbaikan) dalam satuan jam. Mesin yang akan dianalisa pada penelitian ini adalah mesin Pellet Mill 5.12 dan Pellet Mill 8.12 .

\section{Langkah Analisis}

Langkah analisis yang digunakan dalam penelitian sebagai berikut.

1. Mendeskripsikan karakteristik data lama mesin bekerja dan lama perbaikan mesin.

2. Melakukan pemeriksaan trend pada data lama mesin bekerja dan lama perbaikan mesin.

3. Mengestimasi parameter $\ln r, \alpha, \sigma_{e}^{2}$ untuk data umur mesin dan lama perbaikan.

4. Melakukan pengujian Geometric Process pada umur mesin mesin dan lama perbaikan mesin.

5. Melakukan estimasi mean dan varians dari $G_{n}$.

6. Menghitung rata-rata biaya jangka panjang dengan dengan mencobakan jumlah kerusakan (N) dan membuat kurva antara $l_{I}(\mathrm{~N})$ terhadap $\mathrm{N}$.

7. Mendapatkan optimasi waktu optimal pemeliharaan dengan meminimumkan biaya kerusakan mesin pada

8. Menarik kesimpulan dari hasil analisis.

\section{HASIL DAN PEMBAHASAN}

\section{A. Karakteristik Data}

Karakteristik mesin dapat diketahui dengan melihat bagaimana statistika deskriptif dari data variabel umur mesin dan lama waktu perbaikan.

Tabel 1 Statistika Deskriptif Umur Mesin dan Lama Waktu Perbaikan

\begin{tabular}{ccccccc}
\multicolumn{7}{c}{$(\mathrm{jam})$} \\
\hline Variabel & Mesin & $\mathbf{N}$ & Mean & Variance & Min & Max \\
\hline Lifetime & 5.12 & 22 & 1.552 & 2.409 .947 & 96 & 5728 \\
(jam) & 8.12 & 15 & 1.980 & 919.633 & 112 & 5824 \\
\hline Downtime & 5.12 & 22 & 0,962 & 0,791 & 0,083 & 3,5 \\
(jam) & 8.12 & 15 & 0,672 & 0,315 & 0,083 & 1,75 \\
\hline
\end{tabular}

Dari Tabel 1 menunjukkan bahwa jumlah kerusakan

yang dialami oleh kedua mesin berbeda. Mesin Pellet Mill 5.12 lebih sering mengalami kerusakan dibandingkan dengan mesin Pellet Mill 8.12 pada tahun 2012 hingga tahun 2017. Jika dilihat dari rata-rata umur mesin, mesin Pellet Mill 5.12 memiliki rata-rata umur lebih pendek dibandingkan mesin Pellet Mill 8.12. Umur terpendek mesin Pellet Mill 5.12 sampai mengalami kerusakan adalah 96 jam, lebih singkat dibandingkan dengan mesin Pellet Mill 8.12. Hasil tersebut sesuai dengan usia mesin Pellet Mill 5.12 yang sudah lama beroperasi dibandingkan dengan Pellet Mill 8.12 sehingga lebih sering mengalami kerusakan. Rata-rata mesin Pellet Mill 5.12 diperbaiki selama 0,962 jam atau sekitar 57 menit, sementara pada mesin Pellet Mill 8.12 rata-rata mesin diperbaiki selama 0,672 jam atau 40 menit.

Selain menggunakan statistika deskriptif, karakteristik data mesin dapat dilihat melalui plot variabel kumulatif umur mesin (lifetime).

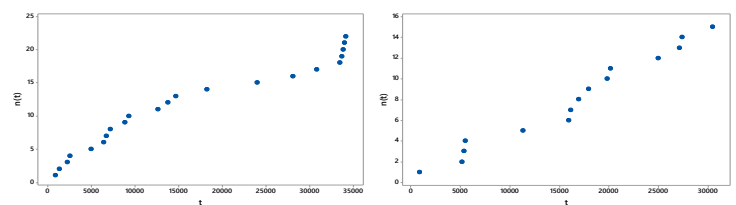


(a)

(b)

Gambar 2 Plot Kumulatif Umur Mesin (t) dan Banyaknya Kerusakan N Mesin Pellet Mill 5.12 (a) dan Pellet Mill 8.12 (b)

Gambar 2 merupakan plot antara banyak kerusakan yang terjadi (N) dengan kumulatif umur mesin (T). Berdasarkan Gambar 2, terlihat jarak antar titik plot pada (a) semakin sempit seiring dengan berjalannya waktu, sementara jarak antar titik plot (b) lebih lebar seiring dengan berjalannya waktu. Jarak titik plot yang semakin sempit menandakan mesin Pellet Mill 5.12 semakin cepat mengalami kerusakan seiring dengan berjalannya waktu. Diasumsikan bahwa mesin Pellet Mill 5.12 ada indikasi memiliki trend naik atau laju kerusakan yang meningkat sementara pada mesin Pellet Mill 8.12 memiliki trend turun. Adanya trend pada data dapat dimodelkan dengan NonHomogeneus Poisson Process [2].

B. Pemeriksaan Trend Data Umur Mesin dan Lama Waktu Perbaikan

Langkah awal yang harus dilakukan sebelum analisa selanjutnya adalah melakukan pemeriksaan apakah data waktu kerusakan dan lama waktu perbaikan memiliki trend atau tidak sebagai dugaan awal data berasal dari Geometric Process. Pada Tabel 2 menunjukkan hasil statistik L untuk data umur mesin bertanda negatif yang artinya terdapat trend menurun. Trend yang menurun berarti laju kerusakan pada kedua mesin semakin menurun atau umur mesin semakin lama semakin meningkat seiring berjalannya waktu. Jika dibandingkan dengan plot kumulatif pada Gambar 2 (a), mesin Pellet Mill 5.12 memiliki jarak antar titik plot yang sempit, namun ada yang memiliki jarak antar titik plot yang jauh. Hal ini bisa saja menyebabkan hasil perhitungan menunjukkan adanya trend yang menurun, bukan meningkat. Sementara untuk mesin Pellet Mill 8.12 yang menghasilkan nilai $L$ negatif, sesuai dengan visualisasi Gambar 2(b).

Tabel 2 Nilai Laplace Data Umur Mesin dan Lama Waktu Perbaikan Mesin Pellet Mill

\begin{tabular}{ccc}
\hline \multirow{2}{*}{ Data } & Variabel & Statistik \\
\cline { 3 - 3 } Mesin Pellet Mill 5.12 & Umur mesin & L \\
\hline \multirow{2}{*}{ Mesin Pellet Mill 8.12 } & Lama waktu perbaikan & $-0,8697$ \\
& Uamur mesin & $-0,4358$ \\
\hline
\end{tabular}

Nilai statistik L untuk data lama waktu perbaikan pada kedua mesin bertanda negatif artinya data lama waktu perbaikan memiliki trend yang turun. Hal tersebut menunjukkan bahwa kegiatan perbaikan yang dilakukan oleh perusahaan masih belum optimum, karena lama waktu perbaikan semakin lama meningkat seiring dengan berjalannya waktu. Adanya trend pada data umur mesin dan lama waktu perbaikan diduga data berasal dari Geometric Process. Untuk membuktikan dugaan tersebut, maka dapat dilakukan pengujian lebih lanjut.

C. Estimasi Paramater $\ln \hat{r}, \hat{\alpha}, \hat{\sigma}_{e}^{2}$ untuk Umur Mesin dan Lama Waktu Perbaikan Mesin Pellet Mill

Sebelum melakukan pengujian Geometric Process, perlu dilakukan perhitungan estimasi parameter $\ln \hat{r}, \hat{\alpha}, \hat{\sigma}_{e}^{2}$.
Estimasi parameter pada perhitungan ini dilakukan menggunakan metode Least Square (kuadrat terkecil).

Tabel 3 Estimasi Parameter Umur Mesin dan Lama Waktu Perbaikan Pellet Mill

\begin{tabular}{|c|c|c|c|c|}
\hline \multirow{2}{*}{$\begin{array}{c}\text { Param } \\
\text { eter }\end{array}$} & \multicolumn{2}{|c|}{ Umur Mesin } & \multicolumn{2}{|c|}{$\begin{array}{c}\text { Lama Waktu } \\
\text { Perbaikan }\end{array}$} \\
\hline & $\begin{array}{c}\text { Pellet Mill } \\
5.12\end{array}$ & $\begin{array}{c}\text { Pellet Mill } \\
8.12\end{array}$ & $\begin{array}{l}\text { Pellet Mill } \\
5.12\end{array}$ & $\begin{array}{c}\text { Pellet Mill } \\
\mathbf{8 . 1 2}\end{array}$ \\
\hline $\ln \hat{r}$ & 0,59341 & 0,74077 & 2,4381 & 3.55291 \\
\hline$\hat{r}$ & 1,81014 & 2,09755 & 11,402 & 34.9146 \\
\hline$\alpha$ & 4,32826 & 3,47712 & 15,962 & 14.9971 \\
\hline$\hat{\sigma}_{e}^{2}$ & 0,78773 & 2,38709 & 8,7037 & 12.4921 \\
\hline
\end{tabular}

Berdasarkan Tabel 3, parameter $\widehat{r}$ pada umur mesin memiliki nilai lebih dari 1 untuk kedua mesin. Hal ini megindikasikan bahwa seiring dengan pemakaian mesin Pellet Mill, maka lama mesin bekerja atau umur mesin semakin pendek dan terus memendek sehingga mesin akan sering mengalami kerusakan. Estimasi parameter variansi $\hat{\sigma}_{e}^{2}$ tergolong kecil, yaitu sebesar 0,78773 untuk mesin Pellet Mill 5.12 dan 2,38709 untuk mesin Pellet Mill 8.12. Nilai variansi yang kecil menunjukkan bahwa parameter yang dihasilkan model regresi untuk usia mesin pada mesin Pellet Mill cukup baik menangkap kejadian kebedaraan trend.

Estimasi $\widehat{r}$ untuk lama waktu perbaikan pada kedua mesin menghasilkan nilai lebih besar dari 1 . Hal ini berarti lama waktu perbaikan mesin Pellet Mill akan semakin berkurang atau cenderung menuju ke 0 . Estimasi parameter varians untuk kedua mesin tergolong kecil yaitu 8,7037 dan 12.4921. Hal ini menunjukkan estimasi parameter yang dihasilkan model regresi untuk lama waktu perbaikan pada mesin Pellet Mill cukup baik menangkap kejadian keberadaan trend.

D. Pengujian Geometric Process Umur Mesin dan Lama Perbaikan Mesin Pellet Mill

Pengujian ini dilakukan untuk mengetahui apakah umur mesin dam lama perbaikan mesin Pellet Mill 5.12 dan Pellet Mill 8.12 berasal dari Geometric Process atau tidak.

Tabel 4 Statistik Uji Umur Mesin dan Lama Perbaikan Mesin

\begin{tabular}{cccc}
\multicolumn{3}{c}{ Pellet Mill } & \\
\hline \multirow{3}{*}{ Mesin } & \multicolumn{2}{c}{ Statistik Uji } & Titik \\
\cline { 2 - 3 } & Umur & Lama Perbaikan & Kritis \\
\hline Pellet Mill 5.12 & -19.8957 & Mesin & 2,08596 \\
Pellet Mill 8.12 & -8.02283 & -24.5486 & 2.16037 \\
\hline
\end{tabular}

Berdasarkan pada Tabel 4, menunjukkan bahwa kedua mesin memiliki nilai statistik uji yang lebih besar dari nilai kritis $\left(|\mathrm{t}|>\mathrm{t}_{\mathrm{n}, 0.025}\right)$, sehingga $\mathrm{H}_{0}$ ditolak dengan tingkat signifikan 5\%. Dapat disimpulkan bahwa kedua mesin berasal dari data Geometric Process. Hal ini menunjukkan bahwa mesin yang mengalami kerusakan kemudian diperbaiki memiliki kinerja yang akan menurun seiiring dengan berjalannya waktu. Serta tingkat laju kerusakan mesin terus semakin meningkat.
E. Estimasi Mean Umur Mesin dan Lama Perbaikan Mesin Pellet Mill

Selanjutnya dilakukan estimasi mean untuk mengetahui mean atau rata-rata lama waktu mesin Pellet 
Mill bekerja dengan baik dan lama mesin dalam kondisi perbaikan.

1. Estimasi Rata-rata Umur Mesin Pellet Mill

Estimasi rata-rata umur mesin Pellet Mill dilakukan menggunakan persamaan (7) sehingga didapatkan hasil sebagai berikut.

Tabel 5 Estimasi Rata-rata Umur Mesin Pellet Mill

\begin{tabular}{ccc}
\hline $\begin{array}{c}\text { Estimasi } \\
\text { Paramater }\end{array}$ & Pellet Mill 5.12 & Pellet Mill 8.12 \\
\hline $\boldsymbol{\mu}_{\boldsymbol{X 1}}$ (tahun) & 2,61791 & 2.72956 \\
$\boldsymbol{\mu}_{\boldsymbol{X} \mathbf{1}}$ (jam) & 15288,596 & 15940,608 \\
$\boldsymbol{\mu}_{\boldsymbol{G} \boldsymbol{n}}$ & $15288,6 / 1,81^{\wedge} \mathrm{n}-1$ & $15940,6 / 2,1^{\wedge} \mathrm{n}-1$ \\
\hline
\end{tabular}

Berdasarkan Tabel 5 didapatkan informasi bahwa rata-rata umur mesin Pellet Mill di PT Japfa Comfeed Indonesia bekerja dengan baik untuk pertama kali adalah selama 15289 jam (Pellet Mill 5.12) dan selama 15941 jam (Pellet Mill 8.12). Kemudian, Tabel 4.6 merupakan hasil perhitungan untuk rata-rata umur mesin bekerja dengan baik setelah mengalami kerusakan ke $\mathrm{n}$.

Tabel 6 Estimasi Rata-rata Umur Mesin Pellet Mill Berfungsi Baik

\begin{tabular}{ccc}
\hline \multirow{2}{*}{ N } & \multicolumn{2}{c}{ Usia Mesin } \\
& Pellet Mill 5.12 & Pellet Mill 8.12 \\
\hline 1 & 15289 & 15941 \\
2 & 8446 & 7600 \\
3 & 4666 & 3623 \\
$\ldots$ & $\ldots$ & $\ldots$ \\
15 & 4 & 0 \\
16 & 2 & \\
17 & 1 & \\
18 & 1 & \\
19 & 0 & \\
\hline
\end{tabular}

Berdasarkan hasil perhitungan pada Tabel 6, mesin Pellet Mill 5.12 tidak dapat beroperasi kembali setelah 18 kali mengalami kerusakan dan mesin Pellet Mill 8.12 setelah 14 kali mengalami kerusakan. Diperkirakan ratarata mesin bekerja dengan baik secara menyeluruh untuk mesin Pellet Mill 5.12 adalah 34160 jam dan untuk mesin Pellet Mill 8.12 adalah 30464 jam. Supaya mesin Pellet Mill dapat bekerja kembali dengan baik maka perlu dilakukan preventive maintenance dengan melakukan pengecekan seluruh komponen mesin dan melakukan penggantian komponen mesin dengan komponen yang baru.

2. Estimasi Rata-rata Lama Waktu Perbaikan Mesin Pellet Mill

Hasil estimasi rata-rata untuk data lama perbaikan mesin menggunakan persamaan (9). Berikut merupakan hasil rata-rata lama perbiakan mesin mesin Pellet Mill.

Tabel 7 Estimasi Rata-rata Lama Perbaikan Mesin Pellet Mill

\begin{tabular}{ccc}
\hline $\begin{array}{c}\text { Estimasi } \\
\text { Paramater }\end{array}$ & Pellet Mill 5.12 & Pellet Mill 8.12 \\
\hline $\boldsymbol{\mu}_{\boldsymbol{Y} \mathbf{1}}$ (tahun) & 0,0022 & 0,0011 \\
$\boldsymbol{\mu}_{\boldsymbol{Y} \mathbf{1}}$ (jsm) & 19,31 & 9,7945 \\
$\boldsymbol{\mu}_{\boldsymbol{G n}}$ & $19,31 / 11,4^{\wedge} \mathrm{n}-1$ & $9,7945 / 34,9^{\wedge} \mathrm{n}-1$ \\
\hline
\end{tabular}

Berdasarkan Tabel 7 didapatkan informasi bahwa ratarata lama perbaikan mesin Pellet Mill di PT Japfa Comfeed Indonesia pada pertama kali mengalami kerusakan adalah selama 19,3 jam untuk mesin Pellet Mill 5.12 dan selama 9,8 jam untuk mesin Pellet Mill 8.12. Kemudian, Tabel 4.8 merupakan hasil perhitungan untuk rata-rata lama mesin diperbaiki setelah beberapa kali mengalami kerusakan ke-n.

Tabel 8 Estimasi Rata-rata Mesin Pellet Mill Mengalami Perbaikan (Jam)

\begin{tabular}{ccc}
\hline \multirow{3}{*}{ Usia Mesin } \\
& Pellet Mill 5.12 & Pellet Mill 8.12 \\
\hline 1 & 19,31 & 9,79 \\
2 & 1,69 & 0,28 \\
3 & 0,15 & 0 \\
4 & 0,01 & \\
5 & 0 & \\
\hline
\end{tabular}

Berdasarkan hasil perhitungan pada Tabel 8 diketahui bahwa rata-rata lama waktu perbaikan mesin Pellet Mill 5.12 adalah 0 sampai 4 kali kerusakan dan mesin Pellet Mill 8.12 adalah 0 sampai 2 kali kerusakan. Hal ini menunjukkan bahwa perusahaan tidak akan melakukan perbaikan kepada salah satu komponen setelah mengalami kerusakan ke-4 atau ke-2. Rata-rata mesin mengalami perbaikan secara menyeluruh adalah 21,17 jam untuk mesin 5.12 dan 10,07 jam untuk mesin 8.12.

F. Penentuan Waktu Kebijakan Optimum Preventive Maintenance

Dalam menentukan model optimasi yang tepat, diperlukan nilai cost of failure dan cost of replacement. Nilai tersebut berupa estimasi biaya berdasarkan informasi yang diperoleh dari PT Japfa Comfeed Indonesia, Tbk. Unit Margomulyo.

Tabel 9 Estimasi Biaya

\begin{tabular}{ccc}
\hline & Mesin 1 & Mesin 2 \\
\hline Lost Production & 8 ton / jam & 15 ton / jam \\
Harga Produk & $6500 / \mathrm{kg}$ & $6500 / \mathrm{kg}$ \\
Biaya Pekerja & $\mathrm{Rp} 18000 / \mathrm{jam}$ & $\mathrm{Rp} 18000 / \mathrm{jam}$ \\
Biaya Perbaikan & Rp 2.500.000/jam & Rp 5.500.000/jam \\
Biaya Penggantian & Rp 22.000.000 & Rp 38.000.000 \\
\hline
\end{tabular}

Nilai estimasi biaya tersebut kemudian disubtitusikan kedalam persamaan (13) yang merupakan fungsi rata-rata biaya perbaikan dan atau penggantian jangka panjang. Berikut merupakan fungsi rata-rata biaya untuk mesin Pellet Mill 5.12(a) dan Pellet Mill 8.12(b).

$$
\begin{aligned}
& l(N)=\frac{54.536 .000 \mu_{Y_{1}} \sum_{n=1}^{N-1} \frac{1}{b^{n-1}}+22.000 .000-\mu_{X_{1}} \sum_{n=1}^{N} \frac{1}{a^{n-1}}}{\mu_{X_{1}} \sum_{n=1}^{N} \frac{1}{a^{n-1}}+\mu_{Y_{1}} \sum_{n=1}^{N-1} \frac{1}{b^{n-1}}} \\
& l(N)=\frac{103.036 .000 \mu_{Y_{1}}^{N-1} \frac{1}{n=1} \frac{1}{b^{n-1}}+38.000 .000-\mu_{X_{1}} \sum_{n=1}^{N} \frac{1}{a^{n-1}}}{\mu_{X_{1}} \sum_{n=1}^{N} \frac{1}{a^{n-1}}+\mu_{Y_{1}} \sum_{n=1}^{N-1} \frac{1}{b^{n-1}}}
\end{aligned}
$$

Selanjutnya didapatkan hasil rata-rata biaya jangka panjang untuk kedua mesin dengan plot antara $l_{l}(N)$ dengan $N$ sebagai berikut. 

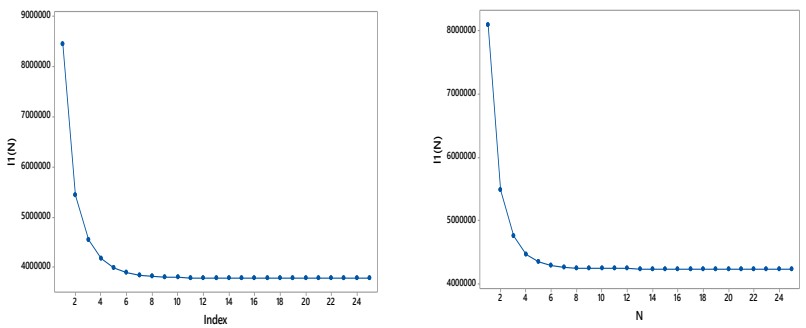

Gambar 3 Plot Jumlah Kerusakan (N) dengan Rata-rata Biaya Mesin Pellet Mill 5.12 (a) dan Mesin Pellet Mill 8.12 (b)

Pada Gambar 3 memberikan informasi mengenai estimasi rata-rata biaya jangka panjang perbaikan dan penggantian komponen die press untuk kedua mesin. Dapat dilihat Gambar 3 menunjukkan estimasi rata-rata biaya jangka panjang kedua mesin semakin lama akan semakin menurun seiring dengan jumlah kerusakan yang telah dialami oleh mesin. Meskipun semakin lama biaya semakin menurun, namun mesin Pellet Mill yang mengalami beberapa kali kerusakan menyebabkan umur dari mesin akan semakin menurun sehingga semakin sering mengalami perbaikan. Perbaikan juga semakin tidak efektif karena semakin lama waktu perbaikan semakin bertambah. Penurunan umur mesin setelah dilakukan perbaikan dapat dilihat pada Tabel 6. Hal yang dilakukan untuk mengantisipasi seringnya terjadi kerusakan adalah melakukan pemeliharaan (preventive maintenance) dengan mengecek keseluruhan komponen dan mengganti komponen die press dengan yang baru. Mengacu pada Gambar 3, kegiatan pemeliharaan pada kedua mesin yang optimum adalah saat mesin mengalami kerusakan ke-8 dan ke-7. Estimasi biaya pada kerusakan ke-8 atau ke-7 dan seterusnya cenderung stationer dengan selisih biaya yang tidak terlalu signifikan dan tidak memiliki arti bagi perusahaan. Selain itu, mengacu pada Tabel 6 apabila perusahaan tidak melakukan pemelihaaraan pada kerusakan ke-8 maka mesin Pellet Mill 5.2 hanya dapat bekerja selama 240 jam atau sekitar 15 hari dan apabila perusahaan tidak melakukan pemeliharaan pada kerusakan ke-7 maka mesin Pellet Mill 8.12 hanya dapat bekerja selama 187 jam atau 12 hari. Hal ini dapat menganggu proses produksi karena mesin harus diperbaiki kembali dalam jangka waktu yang pendek. Oleh karena itu, kegiatan pemeliharaan yang optimum pada mesin Pellet Mill 5.12 adalah saat kerusakan ke-8 dengan estimasi biaya sebesar Rp 3.812.096 perjam dan pada mesin Pellet Mill 8.12 pada kerusakan ke-7 dengan estimasi biaya sebesar 7.344.398 perjam.

\section{KESIMPULAN DAN SARAN}

\section{A. Kesimpulan}

Berdasarkan hasil analisa dan pembahasan, didapatkan kesimpulan bahwa waktu optimum PT Japfa Comfeed Indonesia, Tbk. Unit Margomulyo untuk melakukan kegiatan pemeliharaan pada mesin Pellet Mill 5.12 adalah saat mesin mengalami kerusakan ke-8 dengan estimasi ratarata biaya sebesar Rp Rp 3.812 .096 perjam. Waktu optimum untuk melakukan pemeliharaan pada mesin Pellet Mill 8.12, adalah saat kerusakan ke-7 dengan estimasi ratarata biaya sebesar $\operatorname{Rp} 7.344 .398$ perjam. Kegiatan pemeliharaan berupa pengecekan seluruh komponen mesin serta melakukan penggantian komponen die press.

B. Saran

Berdasarkan hasil analisa dan pembahasan didapatkan beberapa saran untuk perusahaan sebagai berikut.

1. Kegiatan pemeliharaan pada mesin Pellet Mill 5.12 dilakukan saat mesin mengalami kerusakan ke-8 dan mesin Pellet Mill 8.12 dilakukan saat mesin mengalami kerusakan ke-7.

2. Sebaiknya pencatatan data terkait data kerusakan mesin di PT Japfa Comfeed Indonesia, Tbk. Unit Margomulyo lebih diperinci dan diperjelas komponen yang diperbaiki, agar dapat dilakukan perhitungan pemeliharaan yang lebih tepat dan sesuai.

3. Sebaiknya untuk mendapatkan waktu optimum pemeliharaan (preventive maintenance) yang tepat, maka penelitian selanjutnya dapat menggunakan metode yang mempertimbangkan tingkat penururnan yang tidak sama disetiap kerusakan dan perbaikan.

\section{DAFTAR PUSTAKA}

[1] D. W. Ariani, Pengendalian Kualitas Statistik Pendekatan Kuantitatif dalam Manajemen Kualitas, Yogyakarta: Andi, 2004.

[2] S. Rigdon and A. Basu, Statistical Methods for the Reliability of Repairable System, New York: John Wiley \& Sons, 2000.

[3] Y. Lam, "Nonparametric Inference for Geometric Processes," Communications in Statistics - Teory and Methods, pp. 2083-2105, 1992.

[4] F. K. Leung and C. Fong, "A Repair-Replacement Study for Gearboxes Using Geometric Processes," International Journal of Quality \& Reliability Management, vol. 17, no. 3, pp. 285-304, 2000.

[5] P. Permatasari, "Optimasi Waktu Penggantian Komponen Air Cycle Machine (ACM) Pesawat Terbang CRJ-1000 Menggunakan Metode Geometric Process," Jurnal Sains dan Seni ITS, vol. 5, 2016.

[6] Y. Lam, "A Note on the optimal replacement problem," Advances in Applied Probability, pp. 479-482, 1988.

[7] T. C. Adams, "John F Kenedy Space Center," [Online]. Available: https://kscddms.ksc.nasa.gov/Reliability/Document/Laplac e_Test.pdf. [Accessed 6 Juni 2017].

[8] G. J. Wang and Y. L. Zhang, "Geometric Process model for a system with inspections adn preventive repair," Computers \& Industrial Engineering, pp. 13-19, 2014. 